\title{
CLOUDS OVER INTERNATIONAL EFFORTS TO UNIFY RULES OF CONFLICT OF LAWS
}

\author{
KuRT H. NADELMANN*
}

\section{INTRODUCTION}

In this journal which specializes in producing symposia on important topics, ${ }^{1}$ the Spring 1965 issue was devoted to "Unification of Law."2 The subject then had new actuality. To protect the national interest, state and federal, the United States had decided to join the Hague Conference on Private International Law and the International (Rome) Institute for the Unification of Private Law. ${ }^{3}$ Involvement increased with the creation of the United Nations Commission on International Trade Law (UNCITRAL). Today regional work must also be covered. The Organization of American States (OAS) sponsors activities of the "Hague Conference" type. And there are the international agencies attending to special fields such as maritime law and air law. A huge mass of activity is involved. These developments are slow in showing results, but they are generally recognized as necessary. Conventions on important subjects are produced. Most of them take effect, between a larger or smaller number of countries. Independent of ratifications, preparation and existence of the instruments often has beneficial effects. Undesirable practices are brought to light and perhaps stopped. The matter appears in new light.

The United States is among the countries which have ratified the Hague Conventions on Service Abroad of Documents ${ }^{4}$ and on Taking Evidence Abroad. 5 The United Nations Convention on Recognition and Enforcement of Foreign Arbitral Awards also has been ratified (for the commerce field). ${ }^{6}$

* Research Scholar Emeritus, Harvard Law School.

1. The journal is, of course, a creation of the innovator David F. Cavers.

2. 30 Law \& Contemp. Prob. $231-459$ (1965). The Autumn 1963 issue had been on "New Trends in the Conflict of Laws," equally instructive. 28 LAw \& Contemp. Prob. 673-869 (1963).

3. On the basis of Congressional authorization, 22 U.S.C. $\S 269 \mathrm{~g}$. See Nadelmann, The United States Joins the Hague Conference on Private International Law, 30 LAW \& Contemp. Prob. 291 (1965), reprinted in K. Nadelmann, Conflict of Laws: International and Interstate 99 (1972) [hereinafter cited as CoNFLICT of LAws].

4. Convention of Nov. 15, 1965, 20 U.S.T. 361, T.I.A.S. No. 6638, 658 U.N.T.S. 163. Text also in Fed. R. Civ. P. 4, Notes (Supp. 1977). See Amram, United States Ratification of the Hague Convention on Service of Documents Abroad, 61 AM. J. INT'L L. 1019 (1967).

5. Convention of March 18, 1970, 23 U.S.T. 2555, T.I.A.S. No. 7444, 847 U.N.T.S. _ _ Text also in 28 U.S.C. $\S 1781$, Notes (Supp. 1977). See Amram, United States Ratification of the Hague Convention on the Taking of Evidence Abroad, 67 AM. J. INT'L L. 104 (1973).

6. Convention of June 10, 1958, 21 U.S.T. 2517, T.I.A.S. No. 6997, 330 U.N.T.S. 38. Text also in 9 U.S.C.A. $\$ 201$, Notes (Supp. 1977). See Quigley, Convention on Foreign Arbitral Auards, 
Ratification of other Conventions is under consideration. ${ }^{7}$ In some instances, the climate must have become "right" at home and abroad.

Because of the quantity, but also because of the type of work involved, the activity puts a considerable burden on governmental machinery. Familiarity with domestic and foreign law being necessary, heavy reliance on assistance from outside the Administration is unavoidable. The chores include selection of experts, supervision of the work, preparation and coverage of international meetings, evaluation of results. The work load has been growing steadily. Both manpower and financial problems arise. After more than a decade of activity, the operation is still without a permanent berth in the administrative set-up. Resulting uncertainties have become a matter of concern to persons in a position to observe operations.

The decision to join the Hague Conference and the Rome Institute was followed by the creation within the Department of State of an Advisory Committee on Private International Law with the Legal Adviser as Chairman. Leading national organizations were invited to nominate representatives. ${ }^{8}$ The Committee meets two or three times a year. The Department of Justice is represented. Reports by the expert groups are examined and positions developed for coming international meetings. The increased working load in 1970 led to appointment of an Executive Director to the Committee, a position which has been vacant for some time. For the research side a large foundation grant had been obtained early. Smaller grants were secured later. Thereafter, for a while the entire operation was in a crisis. Difficulties still remain. Review of the entire situation has been promised. Consequently, nothing further needs to be said at this time.

After this opening aside, I turn to the topic of this paper, the new difficulties encountered in unification-of-law work on the international level, especially those affecting private international law. They have political aspects in addition to legal. At the risk of oversimplification, it may be said that regional and international interests seem to clash. One incident has become widely known, involving the Common Market Convention on Jurisdiction and Enforcement of Judgments and the treatment given non-residents of the Market. Difficulties of a similar type seem to be on the way. Even within the Organization of American States differences have developed. The future of the Hague Conference has become clouded. The problems need to be aired. A sketch is presented of what is involved.

58 A.B.A.J. 821 (1972). Cf. Domke, The United States Implementation of the United Nations Arbitral Convention, 19 Ам. J. Comp. L. 575 (1971).

7. In first place is the Hague Convention of Oct. 5, 1960, Abolishing the Requirement of Legalization for Foreign Public Documents, 527 U.N.T.S. 189, 9 AM. J. Comp. L. 701 (1960). Text with Analysis by ABA Section of International Law, 9 Int'L LAw. 755 (1975). See Amram, Towards Easier Legalization of Foreign Public Documents, 60 A.B.A. J. 310 (1974).

8. See Kearney, Progress Report-International Unification of Private Law, 23 THE ReCord of THE Ass'n of the Bar of The City of N.Y. 220, 224 (1968). 


\section{UNIFORM Laws on THE INTERnational Sale of GoOdS}

The first international conference which the United States had to attend under the new policy sanctioned by the Congress ${ }^{9}$ was one called for April 1964 by the Netherlands Government at the request of the Rome Institute to work on two drafts, a convention providing for a uniform law on the international sale of goods and one providing for a uniform law on the formation of contracts for such sales. A draft of a uniform sales law had been prepared by the Rome Institute before the Second World War. After the War it was put before a diplomatic Conference which sat at The Hague in October 1951 and turned it over to a committee for improvements. ${ }^{10} \mathrm{~A}$ revised draft and a first draft of a uniform law on formation reached the involved governments in 1956.

The United States had not taken part in preparation of the drafts or in the 1951 Conference. Ernst Rabel, an original sponsor of the Rome Institute project and since the outbreak of the War a resident of Ann Arbor, had attended the Conference as a Rome Institute Consultant. The Rabel "link" had gone with his death in 1955. The Rome Institute was familiar with the work on our Uniform Commercial Code and also was aware of moves made in the United States to join the Rome Institute and the Hague Conference.

The United States faced the problems of the Diplomatic Conference called for April 1964 with little advance notice. From the American viewpoint the drafts were defective and required amendments. The Conference's history is recorded; its proceedings are in print. At a pre-Conference meeting the Common Market countries had agreed not to allow a postponement. They commanded a majority at the Conference. At the end of three weeks' work the drafts were brought to a vote and approved by a majority. ${ }^{11}$

The United States was in the uncomfortable position of a latecomer. The British had taken part from the beginning and did not wish to antagonize the Continent. At their suggestion, ratification of the Convention was allowed with the reservation that the uniform laws should apply only if chosen as the law of the contract by buyer and seller. ${ }^{12}$ Such "ratification" would count as one of the five needed to put the Conventions into effect.

Aside from this phenomenon, a provision in the Uniform Law itself has made history. Article 2 forbids recourse to the rules of private international law to govern the Law's application. No limit on applicability is needed, it was

9. See note 3, supra.

10. See Rabel, The Hague Conference on the Unification of Sales Law, 1 Aм. J. Comp. L. 58 (1952).

11. See Honnold, The Uniform Law for the International Sale of Goods: The Hague Convention of 1964, 30 Law \& Contemp. Prob. 326 (1965). For the text of the two Conventions of July 1, 1964, the Principal Convention and the Formation Convention (the uniform laws are in appendix) see, respectively, $i d$. at 425 and $451 ; 13$ AM. J. Comp. L. 453 and 472 (1964).

12. Principal Convention, supra note 11 , Art. V. 
argued, uniform legislation drafted by an international conference being superior to any local law. A United States proposal to remove this post-Rabel provision was lost by a vote of eleven versus eleven with two abstentions. ${ }^{13}$ Concessions were made. Ratification may be with the reservation that buyer and seller must each be in a country party to the Convention. ${ }^{14}$ Countries that were parties to the Hague Conference Convention of 1955 on Choice of Law in International Sales ${ }^{15}$ secured another reservation: The Uniform Law shall apply only if the Conflicts Convention's choice-of-law rule points to the Uniform Law. ${ }^{16}$

Views differ on whether it was "right" to vote on an admittedly defective draft and deny the United States a proper chance of influencing the contents. Agreement exists that ad hoc diplomatic conferences like that held in April 1964 present unusual risks. ${ }^{17}$ The vote on unlimited application of the Uniform Law reflected lack of proper representation of private international law on the delegations. Post-Conference developments, it will be seen, allow the hope that a generally acceptable law on international sales of goods will be produced.

As a result of an initiative taken by Hungary in the fall of 1964 , the United Nations Commission on International Trade Law was created in 1966. The Commission in 1968 decided to give first priority to production of a uniform law on international sales. ${ }^{18}$ The Working Group which was set up produced a draft. ${ }^{19}$ With some changes it was approved by the Commission at its Tenth Session held in Vienna in June $1977 . .^{20}$ The draft will go before a United Nations Conference. An acceptable answer to the Uniform Law's applicability in space seems to have been found. ${ }^{21}$ The prospects of the project

13. This and other phases of the Conference are discussed critically in Nadelmann, Uniform Legislation Versus International Conventions Revisited, 16 AM. J. CoMP. L. 28, 34-44 (1968); $1967-$ 1968 II Unification of Law Yearbook 173, 179-89, reprinted in Conflict of Laws, supra note 3 , at $141,147-59$.

14. Principal Convention, supra note 11, Art. III; Formation Convention, supra note 11, Art. III.

15. Convention of June 15, 1955 on the Law Applicable to International Sales of Goods, 510 U.N.T.S. 147, 1 Ам. J. СoмP. L. 275 (1952).

16. Principal Convention, supra note 11, Art. IV; Formation Convention, supra note 11, Art. IV.

17. The composition of the Conference and other aspects are discussed in Nadelmann, supra note 13 .

18. See Contini, The United Nations Commission on International Trade Law, 16 Aм. J. CoмP. L. 666, 672 (1968); Farnsworth, UNCITRAL-Why? What? How? When?, 20 Aм. J. Comp. L. 314,317 (1972).

19. For progress reports see the Yearbooks of UNCITRAL published since 1968.

20. Text in Report of UNCITRAL on the work of its tenth session (A/32/17), para. 35, at 11 (1977)

21. "Article $1:$ (1) This Convention applies to contracts of sale of goods entered into by parties whose places of business are in different States: (a) when the States are Contracting States; or (b) when the rules of private international law lead to the application of the law of a Contracting State. (2) ...."Id. 
are considered good. A side product prepared by the Commission, a Convention with a Uniform Law on Prescription (Limitation) in the International Sale of Goods, was approved by a United Nations Conference recently. ${ }^{22}$

The decision taken by UNCITRAL to produce an improved version of a Uniform Sales Law did not deter the activist group of the 1964 Diplomatic Conference from pressing for immediate enactment of the Uniform Laws produced in 1964. Enabling legislation was passed in the United Kingdom as early as $1967 .{ }^{23}$ As a result of five ratifications, the Conventions became effective as of August 1972 between the United Kingdom (with the "British" reservation), Belgium, San Marino, Israel, and the Netherlands. Ratifications by Italy and the German Federal Republic followed. ${ }^{24}$ Only Israel has ratified without the use of any one of the allowed reservations. France and Luxemburg have not ratified. It is too early to assess the results of this semi-regional unification of law. British business has not availed itself of the possibility of making the Uniform Laws the law to govern its international sales contracts; nor has American business chosen the Uniform Laws (which can be done without any need for ratification of the Conventions by the United States). ${ }^{25}$

II

\section{The Common Marker's Convention on Judgments}

After the experience with the April 1964 Diplomatic Conference, the 10th Session of the Hague Conference on Private International Law called for October 1964 had to be covered. A different setting was encountered. At the post-War Conference of 1951 a permanent intergovernmental institution had been created with a Permanent Bureau and regular sessions to be held every four years. Topics on the agenda are prepared in advance of the session at meetings of Expert Commissions. ${ }^{26}$

Three draft conventions were produced at the 1964 Conference. The United States has ratified one, the Convention on Service of Documents Abroad. ${ }^{27}$ Work on the fourth topic, recognition and enforcement of foreign judgments, could not be completed for lack of time and because of a controversy over whether to prepare a multilateral convention or a model for

22. See Smit, The Convention on the Limitation Period in the International Sale of Goods: UNCITRAL's First Born, 23 Am. J. Comp. L. 337 (1975). Text of Convention, id. at 356.

23. See R. Graveson, E. Cohn \& D. Graveson, The Uniform Laws on International Sales ACt 1967, Preface v (1968).

24. See Tunc, L'entrée en vigueur des Conventions de La Haye portant Loi Uniforme sur la vente internationale d'objets mobiliers corporels, 24 REVUE INTERNATIONALE DE DROIT COMPARÉ 416 (1972); Landfermann, Neues Recht für den internationalen Kauf, [1974] Neue Juristische WochenSChrift 385; of. Kropholler, Der "Ausschluss" des Internationalen Privatrechts im Einheitlichen Kaufgesetz, 38 RABELS ZEJTSCHRIFT 372, 377 (1974).

25. Under article 4 of the Uniform Law, supra note 11.

26. The Conference as formed in 1951 is discussed in Nadelmann, supra note 3.

27. Supra note 4. 
conventions. The decision was to call a Special Session to complete the work.

The Conference met in special session in April 1966. The preliminary question was resolved. A multilateral convention would be prepared, but it would take effect between given countries only after they had concluded a complementary agreement. Control over the choice of the partner was preserved. Work on the convention was completed ${ }^{28}$ except for one substantive issue over which violent disagreement developed, threatening to break up the meeting. The issue was the result of outside developments.

Under their Charter, the Treaty of Rome of 1958, the Common Market countries are obliged to facilitate reciprocally the enforcement of the decisions of their courts. In 1960, the six governments decided to comply with the obligation by way of a multilateral convention. The same year, as a result of suggestions from the Council of Europe and the International Law Association, the Hague Conference decided to prepare a convention on judgments.

When the Hague Conference met in Special Session in April 1966, an advance draft of the Market Convention had become known. Among other things, the draft provided that, against non-residents of the Market (but not residents), all judgments must be enforced, even judgments rendered on a jurisdictional ground that has traditionally been held internationally unacceptable-for example, judgments with plaintiff's nationality or domicile or mere presence of assets as basis. But for the treaty, recognition would be denied such judgments. ${ }^{29}$ At the session of the Hague Conference, the United Kingdom and United States delegations jointly proposed regulation in the Hague Convention of the status of judgments rendered by courts without proper jurisdiction. ${ }^{30}$ The Market group objected vehemently. As a last minute compromise it was decided to sign the convention draft and assign the question of the status of such judgments to a Special Commission for resolution. The Commission met in October of the same year and produced a protocol limiting their effects. ${ }^{31}$

The agreement on the protocol was unanimous, but disagreement developed over the relation between protocol and convention. This issue was taken up at the 11 th Session of the Conference held in October 1968. Again a

28. Convention of Feb. 1, 1971 on the Recognition and Enforcement of Foreign Judgments in Civil and Commercial Matters. Text in 15 Ам. J. Comp. L. 362 (1967). See Nadelmann \& von Mehren, The Extraordinary Session of the Hague Conference on Private International Law, 60 AM. J. INT'L L. 803 (1966).

29. See Nadelmann, Jurisdictionally Improper Fora in Treaties on Recognition of Judgments: The Common Market Draft, 67 Colum. L. Rev. 995 (1967), reprinted in Conflict of LAws, supra note 3 , at 238 .

30. Text of proposal in Nadelmann, The Outer World and the Common Market Experts' Draft of a Convention on Recognition of Judgments, 5 Соммом Mкт. L. REv. 409, 419 (1967-68).

31. Supplementary Protocol of Feb. 1, 1971 to the Hague Convention on the Recognition and Enforcement of Foreign Judgments in Civil and Commercial Matters, 15 AM. J. Comp. L. 396 (1967). 
compromise was necessary. A resolution was adopted unanimously recommending that convention and protocol be used together. ${ }^{32}$ The protocol as such has made history but neither it nor the Convention has been used. The multilateral Convention is considered too complicated. The many treaties which have since been concluded ${ }^{33}$ are all bilateral instruments; this form is preferred.

The public debate at The Hague led the Common Market group to make a concession. The system of the Convention was not changed but a provision was added allowing each member State not to enforce foreign judgments rendered by a court without proper jurisdiction, provided the State has with the country of the domicile of the judgment debtor a treaty on recognition of judgments. ${ }^{34}$ Since February 1973 the Market Convention of September 27, 1968 , has been in force among the original Six. The three new members are obliged under the Acts of Accession to adhere to the Convention. If adjustments are found to be needed, they must be negotiated between the new member and the Six as a group. ${ }^{35}$ Such negotiations are underway and close to conclusion.

Domiciliaries of the United States run serious risks. ${ }^{36}$ For example, a plaintiff who is French may on the jurisdictional basis of his nationality sue and obtain judgment in France against a nonresident and then use the judgment for enforcement under the Market Convention in any Market State where the defendant has assets. Or, because some, perhaps insignificant, assets are in Germany, the suit is in the German courts and the judgment given for the entire claim can then be enforced in other Market States. Had the litigation been in a court with proper jurisdiction, judgment might have been for the defendant.

Some time after the United Kingdom had joined the Common Market, a proposal by the United Kingdom to negotiate a convention on recognition of

32. See Nadelmann, The Common Market Judgments Convention and A Hague Conference Recommendation: What Steps Next?, 82 HARv. L. Rev. 1282 (1969), reprinted in 116 Cong. REc. 4936 (Feb. 25, 1970).

33. Leading in the bilateral treaty field is France. See, e.g., Treaty of July 15, 1966 with Austria, 56 Revue critique de droit international PRIVÉ 818 (1967); of May 28, 1969 with Spain, 59 Revue critique de droit international Privé 327 (1970).

34. Art. 59 of the EEC Convention on Jurisdiction and the Enforcement of Judgments in Civil and Commercial Matters. Transl. in 2 Cомм. Мкт. Rep. (CCH) § 6003 (1968). See Lipstein, The Law of the European Economic Community 270-84 (1974); Nadelmann, supra note 29, at 1022; Conflict of Laws, supra note 3, at 268.

35. For the United Kingdom see Act of Accession of Jan. 22, 1972, art. 3(2). EURoPEAN Communities, Office for Official Publications, Treaties Establishing the European Communities-Treaties Amending These Treaties-Documents Concerning the Accessions 888 (1973).

36. See Carl, The Common Market Judgments Convention-Its Threat and Challenge to Americans, 8 INT'L LAw. 446, 449-51 (1974); Nadelmann, supra note 32. 
judgments was received and accepted by the United States. The treaty would free the United Kingdom from the obligation to enforce against United States residents judgments rendered elsewhere in the Market without a proper jurisdictional basis. A draft treaty was initialled by representatives of the two governments ad referendum in October $1976 .{ }^{37}$ If the treaty is signed and ratified, protection is secured for assets located in the United Kingdom. The problem persists in its entirety in the original six member States and, once they have acceded to the Convention, in Denmark ${ }^{37 a}$ and Ireland.

The Six of the Common Market-or persons for them-found it proper to challenge the rest of the world. No legal issue exists; the complaint is considered justified by commentators. ${ }^{38}$ The challenge should be taken up. The Six could be invited to agree on submission of the matter to the International Court of Justice. The test would be "due process of law," a concept which has general standing. ${ }^{39}$

Until corrected, the issue will burden relations with the Common Market. The concession that individual member States may remove the effect complained of through the conclusion of treaties on recognition of judgments with third States will not appease these latter States. Negotiation of treaties is at best a long-drawn-out affair. The Six have not offered to conclude such treaties. The United States as one interested party has no reason to submit to pressure, especially in view of the liberal recognition policy followed by the courts in the United States in the matter of recognition of foreign

37. Convention between the United Kingdom of Great Britain and Northern Ireland and the United States of America Providing for the Reciprocal Recognition and Enforcement of Judgments in Civil Matters. Draft initialled October 26, 1976 ad referendum. Text in 16 INT'L Legal Materials 71 (1977); Cmnd. 6771 (U.S. No. 2, 1977).

37a. In Scandinavia, steps have been taken to protect judgment debtors from the area. A new Convention between Sweden, Denmark, Finland, Iceland, and Norway on Recognition and Enforcement of Judgments in Private Law Matters (Sweden: Prop. 1976/77: 128), designed to replace the Scandinavian Convention of March 16, 1932, prohibits courts from enforcing judgments rendered in a third State on a jurisdictionally improper basis. The local legislation has been brought in line. For Sweden, see Law of June 30, 1977, SFS 1977: 595, On Recognition and Enforcement of Scandinavian Judgments in Private Law Matters. Covered by Article 59 of the Common Market Judgments Convention, Denmark does not have to enforce such judgments rendered in other Market States. Of course, the Convention does not afford protection where enforcement of such judgments is sought in another Market State against assets there located of judgment debtors domiciled in Scandinavia.

38. See, e.g., G. Droz, Compétence judiciaire et effets des jugements dans le Marché Commun (Étude de la Convention de Bruxelles du 27 septembre 1968) 433-48 (1972); M. WESER, Convention Communautaire sur la COMPétence judiciaire et l'Exécution des décisions 110 , $277(1975)$.

39. Compare a recent dictum of the U.S. Supreme Court: "Once it has been determined by a court of competent jurisdiction that the defendant is a debtor of the plaintiff, there would seem to be no unfairness in allowing an action to realize on that debt in a State where the debtor has property, whether or not that State would have jurisdiction to determine the existence of the debt as an original matter." Shaffer v. Heitner, 97 S. Ct. 2569, 2583 n.36 (1977); 16 INT'L LEGAL MATERIALS 885,898 n.36. 
judgments. ${ }^{40}$ This policy, of course, can be changed, by action on the state and the national levels.

III

\section{The Common Market's Draft Bankruptcy Convention}

Bad examples which are tolerated are dangerous. The problem created by the Market Judgments Convention seems to be the forerunner for other difficulties of the same nature. The Market Judgments Convention excludes from coverage decrees in bankruptcy. Conclusion of a separate bankruptcy convention was deemed preferable. After years of work, the draft of a bankruptcy convention prepared by a Working Group was published in $1970 .^{41}$ Again the multilateral convention approach is used. The aim of the draft is to secure liquidation of all the assets in a single administration. Only one bankruptcy adjudication can take place, and it must be given effect in all Market States. Unless provided otherwise, the law of the state of the adjudicating court governs. On a few points the substantive law is made uniform. ${ }^{42}$

Exclusive adjudicatory jurisdiction is given to the courts of the Market State in which the debtor's center of affairs is located. If the center is outside the Market, jurisdiction goes to the court of the place of an establishment in the Market, if there is one; if none exists but local law allows an adjudication on some other ground-perhaps creditor's nationality or domicile or presence of assets-this basis may be used. Whatever the basis, effect must be given to the adjudication in all Market States. ${ }^{43}$ As in the case of the Judgments Convention, extraterritorial effect is given even to strictly local adjudications which would be denied effect abroad under current law. Rights and interests of individual non-Market parties are jeopardized. Again the outside world is challenged.

The 1970 draft went to the six governments for their comments. When the United Kingdom, Denmark and Ireland joined the Market, they were invited to comment on the draft. Unlike the Judgments Convention, no commitment exists with respect to the bankruptcy draft. In the United Kingdom,

40. See Ginsburg, Recognition and Enforcement of Foreign Civil Judgments: A Summary View of the Situation in the United States, 44 INT'L LAw. 720 (1970); [R.] von Mehren \& Patterson, Recognition and Enforcement of Foreign-Country Judgments in the United States, 6 LAw \& Policy IN INT'L Bus. 37 (1974).

41. Unofficial translation, Preliminary Draft of a Convention on Bankruptcy, Winding-up, Arrangements, Compositions and Similar Proceedings, in 2 Coмm. Мкт. ReP. (CCH) $\$ 6612$ (1975); approved transl. in The EEC Preliminary Draft Convention on Bankruptcy, Winding-up, Arrangements, Compositions, and Similar Proceedings, Report of the Advisory Committee, Appendix 10, at 141 (Cmnd. 6602, August 1976) [hereinafter Command Paper].

42. Analysis of the draft in LiPsTEIN, supra note 34, at 284; Fletcher, The Proposed Community Convention on Bankruptcy, I Eur. L. REv. 15 (1977).

43. The jurisdictional rules are discussed in Nadelmann, Rehabilitating International Bankruptcy Law: Lessons Taught by Herstatt and Company, 52 N.Y.U. L. REv. 1, $27-31$ (1977). 
the Secretary of State for Trade in 1973 appointed an Advisory Committee composed of lawyers and accountants from England, Scotland and Northern Ireland (each of which has its own bankruptcy law). The Committee's Report was released in August 1976. ${ }^{44}$ It includes a note of Reservations by one of the six committee members. ${ }^{45}$

A majority of the Committee accepts the single administration approach taken in the draft which, of course, was made with only the original Six in mind. ${ }^{48}$ On the jurisdictional issue a majority think that the questionable feature is acceptable because "otherwise a gap would remain." 4 The note of Reservations-which is by Professor Anton, ${ }^{48}$ currently a member of the Scottish Law Commission-pays special attention to what its author considers provisions unfair to non-member States. ${ }^{49}$ Alternative approaches are offered to the resolution of the problems which the Market faces in the field of bankruptcy. ${ }^{50}$

The Market's Working Group has resumed work. The future of the draft is unclear. The draft fails to deal, even for internal purposes, with the case where assets are outside the Market. ${ }^{51}$ The non-Market country where assets are located will have means of protecting itself from discriminatory or noncooperative aspects of Market law. ${ }^{52}$ Confrontations can be expected. The draftsmen seem to have thought that the Market can do as it pleases without being vulnerable. This is not the case.

International work on the bankruptcy problems is long overdue. ${ }^{53}$ An ef-

44. Command Paper, supra note 41. The Report underlines that the United Kingdom has no obligations toward the draft ( $\$ 4$ in Introductory).

45. Command Paper, supra note 41, at 105-28 (hereinafter Reservations).

46. Command Paper, supra note 41, $\$ 16$; $c f$. Reservations, supra note 45, $\$ \S 18-21$. In the past, England had insisted on a more flexible approach. See Nadelmann, supra note 43 , at 28 n. 155 .

47. Command Paper, supra note 41, § 121; cf. Reservations, supra note 45, 17.

48. Author of the textbook Private International Law (1967).

49. Reservations, supra note $45, \S \S 55-60$.

50. $I d ., \S \S 61-67$.

51. This problem is considered in a paper of mine for a roundtable discussion held in Milan, Italy, in 1970. Nadelmann, The Common Market Bankruptcy Convention Draft: Foreign Assets and Related Problems, in Conflict of Laws, supra note 3, at 340. French, German, and Spanish versions are in, respectively, 6 Rivista di diritTo internazionale Privato e Processuale 501 (1970); 32 Konkurs-, Treuhand- und SChiedsgerichtswesen 68 (1971); 145 Revista Jurídica Argentina LA LEY 705 (1972).

52. The problem is discussed in Nadelmann, supra note 43.

53. The chaotic condition of the law could be witnessed in the recent banking cases discussed in Nadelmann, supra note 43, which also led to adjudications abroad. In Herstatt, "marshalling" is litigated in German courts; in Israel-British, where the equal distribution of the New York assets was secured in our courts, the Swiss assets have gone to the first attaching creditor. See Konkursmasse Israel-British Bank, Swiss Fed. Trib., March 12, 1976, 102 III BGE 71 (law reform being recommended in the opinion). The most recent presentation of the American system is a decision of the U.S. Court of Appeals for the Second Circuit of August 30, 1977. Banque de Financement v. First National Bank of Boston, F.2d (2d Cir. 1977). 3 Bankr. Ct. Dec. 801. 
fort to reactivate work in the International Law Association was blocked by the Market group. ${ }^{54}$ The same situation may be faced at the Hague Conference. $^{55}$ I have elsewhere urged that the governments ask UNCITRAL for an exploratory study. ${ }^{56}$ Agreement on minimum standards for local legislation may turn out to be possible.

\section{IV}

\section{The Common Market Draft Convention on Contracts and Torts and the Hague Conference}

Though in a different way, the Common Market Judgments Convention is linked with yet another Market project which has produced concern in many quarters. After completion of the Judgments Convention, the argument was advanced by some that, inasmuch as the Convention allows choice between courts in certain instances, the choice-of-law rules should also be unified to prevent forum shopping. Identical rules would reduce interest in maneuvering for a court in one State rather than another. But the desirability of unifying the conflicts law had also been argued as a general proposition.

Back in 1951, the Benelux countries had drafted a uniform law on private international law. To remove opposition to some provisions, a revised version was produced in $1967 .{ }^{57}$ This draft was sent by the three governments to the Commission of the European Communities with the proposal that unificationof-law work be undertaken for the entire Market. Consultations between the six governments led to agreement in principle on such a project. A plan on how to proceed was developed. Work was to begin with contracts and torts. Reporters were chosen. After eleven meetings, each lasting several days, the experts early in 1972 agreed on a draft Convention on the Law Applicable to Contractual and Non-Contractual Obligations.58 A supporting statement by the Reporters was produced. ${ }^{59}$ At a meeting of the Market's Working Group in February 1973, also attended by representatives of the three new member

54. See decision of Executive Council of Nov. 15, 1969, International Law Association, Report of 53rd Conference, Buenos Aires, 1968, xxxiii, xxxvi.

55. The latest attempt of the Hague Conference goes back to 1925. See Nadelmann, Bankrupty Treaties, 93 U. PA. L. Rev. 58, 84 (1944), reprinted in Conflict of Laws, supra note 3, at $299,327,336$.

56. Nadelmann, Lex Mercatoria and International Bankruptcies, in 2 New Directions IN INTERnational Trade Law, Acts and Proceedings of the Second International Congress on Private law, Rome 1976, 473, 476 (1977).

57. Translation in 18 AM. J. Comp. L. 420 (1970). See Nadelmann, The Benelux Uniform Law on Private International Law, 18 AM. J. CoMP. L. 406 (1970).

58. French text first in 9 Rivista di diRitto internazionale privato e processuale 189 (1973); also in 103 Journal du Drolt Int'l 653 (1976). See Jacques Foyer, L'avant-projet de Convention C.E.E. sur la loi applicable aux obligations contractuelles et non-contractuelles, id. at 555.

59. Text in 9 Rivista di diritto internazionale. Privato e processuale 198 (1973). 
States, the decision was reached to publish the draft. A translation appeared in the United States. ${ }^{60}$

The rules are designed to be of general application. Under the draft Convention they shall apply without any requirement of reciprocity and irrespective of whether the law to apply is that of a Market State. ${ }^{61}$

When the Hague Conference had its 12th Session in October 1972, consideration was devoted, as usual, to topics for future work. The United States delegation proposed work on contracts and torts. ${ }^{62}$ It argued that regional codification of rules of general applicability, which seemed under way, risked freezing the law, thereby making unification on a broader level difficult if not impossible. Contracts and torts required broad treatment. The Hague Conference had been created to work on the broadest level. The Market group opposed the proposal as a challenge to their right to do for themselves as they saw fit. The substantive argument was that the Conference had always worked on specific, rather than broad subjects. The President of the Session, the late Professor Louis de Winter, said that he saw no reason why the Conference should not investigate the merits of the American proposal. A compromise was reached. The Permanent Bureau would send a questionnaire to the member governments inquiring whether it was opportune to undertake studies on the subject. In the light of the replies, the Standing Government Committee would decide on the action to be taken. ${ }^{63}$

The Standing Government Committee is a Dutch Committee set up in 1897 by the Dutch Government to advise it in the field of private international law. ${ }^{64}$ When at the post-War Conference of 1951 the Hague Conference was transformed into a permanent intergovernmental institution and its Charter was written, ${ }^{65}$ the assignment was given to the Dutch Government Committee to secure the Conference's operation with the help of a Permanent Bureau. The Committee would examine all proposals for the agenda of a Conference session. It would set the session's date and settle the agenda after consultation with the member governments. Between sessions, the Committee

60. EEC Draft Convention on the Law Applicable to Contractual and Non-Contractual Obligations (transl.), 21 AM. J. Comp. L. 587 (1973). Another translation, together with the French text, may be found in European Private International Law of Obligations 230 (O. Lando, B. von Hoffmann \& K. Siehr eds. 1975).

61. EEC Draft, supra note 60, art. 24.

62. Text of statement in Report, The Twelfth Session of the Hague Conference on Private International Law, 21 Ам. J. Comp. L. 136, 137-38 (1973).

63. Text of Resolution in Report, supra note 62, at 163, (V(1)(d)). For the minutes of the discussion, see Conférence de La Haye de Droit International Privé, Actes et Documents de la Douzième Session, Tome I: Matièzes Diverses 92 (Oct. 13, 1972 in Commission IV).

64. See de Winter, Les 75 ans d'existence de la Commission d'Etat néerlandaise pour le droit international privé, 18 TIJDSCHRIFT voOR INTERNATIONAAL RECHT 261 (1971).

65. Text of Charter, in force since July 15, 1955, in 15 U.S.T. 2228, T.I.A.S. No. 5710, 220 U.N.T.S. 121. 
might create special commissions to prepare drafts and order study of topics within the range of Conference interest. ${ }^{66} \mathrm{I}$ might add that the expenses of the regular sessions of the Conference are covered by the Netherlands. ${ }^{67}$

The questionnaire on Contracts and Torts prepared by the Permanent Bureau was sent to the member governments in November $1973 .{ }^{68}$ Should work be undertaken? Should it be parallel to what other organizations were doing or should it be delayed until that other work was in an advanced stage? Should the topics be on the agenda of the 13th (1976) or 14th (1980) Session? The replies were circulated by the Bureau in November 1974 with an evaluation. ${ }^{69}$ The answers seemed to be divided evenly on whether to start work immediately or to wait and, possibly, go into it later. The Government Committee's conclusion was that the topic should not be on the agenda of the 1976 Session. As regards later work, further investigation, the Committee thought, was needed-for example, whether to draft rules of a general nature or special rules, whether the form should be a convention, a model law, or recommendations. Another communication was promised toward the end of 1975 , possibly with the calling of a meeting of a Special Commission to consider this and other matters. In November 1975, a meeting of a Special Commission on Miscellaneous Matters was called for January 19, 1976. ${ }^{70}$ The Permanent Bureau dispatched a memorandum on Contracts and Torts to the Embassies at The Hague at the end of December. ${ }^{71}$ The question of separate work for contracts and torts was raised. The form of codification was discussed with reference to the techniques used in the Benelux Draft, in recent municipal codifications (Italy, Portugal, Czechoslovakia), and in the Restatement (Second) of Conflict of Laws. Other points were considered, among them the range of freedom for the parties to choose the governing law and the problem created by municipal rules of imperative application. ${ }^{72}$

The Special Commission meeting of January 1975 was attended by experts from 17 of the 28 member States: Austria, Belgium, Canada, Czechoslovakia, Denmark, Egypt, Finland, France, Germany, Ireland, Luxemburg, Netherlands, Portugal, Spain, Switzerland, United Kingdom, United States. As ex-

66. Charter, supra note 65 , arts. $3,7$.

67. Charter, supra note 65 , art. 10.

68. Hague Conference, Doc. Prél. No. 1, Contracts and Torts, Nov. 1973, ON No. 36 (73) of Nov. 31, 1973, to appear in Conférence de La Haye de Droit International Privé, Actes et Documents de la Treizième Session, Tome I: Matières Diverses.

69. Hague Conference, Doc. Prél. No. 2, Contracts and Torts, ON No. 33 (74) of Nov. 18,1974 , to appear in $i d$.

70. ON No. $33(75)$ of Nov. 6, 1975, to appear in id.

71. Hague Conference, Miscellaneous Matters, Contracts and Torts, Prel. Doc. No. I, Dec. 29, 1975, ON No. 40 (75), to appeár in id.

72. Art. 7 of the EEC Draft, supra note 60 , at 588 , devoted to the same subject had been the subject of wide criticism. 
pected, the views were divided. An ad hoc committee was asked to propose a compromise. Eventually, the following text was approved: ${ }^{73}$

The positions taken at the Special Commission did not permit a unanimous recommendation that the subject of contracts and torts be included in the future work of the Conference; however, if the 13th Session of the Conference decides to recommend that the Conference proceed with the study of this subject, the Special Commission unanimously recommends the following procedure:

The work on the subject would commence with an internal study to be made by the Permanent Bureau. The scope of this study should be rather broad and should take into account work undertaken on the regional level and in other international organizations. This study would result in a Report which would be submitted to the Netherlands Standing Government Committee, which would then decide on the subsequent steps to be taken, in conformity with standard procedures of the Conference.

A progress report shall be submitted to the 14 th Session. The work shall be conducted so as not to hinder any contemporaneous work being carried on in the field by any regional group.

Special Commissions are on their own; their decisions do not commit the governments. Of interest is the interpretation which the Permanent Bureau gave the Resolution in its Note prepared for the benefit of the 13th Session: ${ }^{74}$

The Permanent Bureau thinks that the studies to which the conclusions of the Special Commission refer should be of such a nature that they would clearly show to the Standing Government Committee and possibly the 14th Session how obligations arising out of contracts and torts are in general dealt with by legislation, by the case law, and by legal writers in the various countries, and also in international organizations, and what the chances are of reaching texts reflecting what may perhaps be found as being common to all these systems of law and individual rules. It is not excluded, for example, that the studies will clearly show that such obligations, whenever they belong to very specified fields such as international payments or intellectual property, should be governed by special rules of conflict which would take into account the particularity of the field in which they will have to come into play.

It will be for the 13th Session to decide the terms in which a possible suggestion to be addressed to the Netherlands Standing Government Committee, and relating to the follow-up to be given to the conclusions of the Special Commission, should be drafted. Doubtless, the Session could limit itself to approving the conclusions of the Special Commission of January 1976 as they are.

Before the events at the 13th Session of the Hague Conference in October 1976 are taken up, a word on the status at that time of the Common Market draft appears indicated. The draft had been discussed at numerous meetings, small and large. After the French Committee on Private International Law in

73. Text in Annex to Hague Conference, Miscellaneous Matters, Contracts and Torts, Prel. Doc. F, August 1976, Note on Contracts and Torts.

74. Note on Contracts and ToRTs, supra note 73, $\S 6$ and 7. 
1973 had devoted a meeting to the draft, an international colloquium took place in Copenhagen on April 29 and 30, 1974. ${ }^{75}$ The drafting group was represented. Specialists from all Scandinavian countries, Ireland and the United Kingdom, Austria and Switzerland were in attendance. A smaller meeting on the draft took place in Brussels in December 1974. In 1975, the Netherlands International Law Association devoted its annual meeting to the draft. In the United Kingdom, the two Law Commissions produced a "Consultative Document" which was circulated in $1975^{76}$ to obtain reactions. ${ }^{77}$ The Market Working Group continued to meet behind closed doors. A meeting had been scheduled for the end of June 1976 in London and some participants were to stay over for the July 1976 Ford Legal Workshop in London, cosponsored by the Institute of Advanced Legal Studies, University of London, and the Law Commission. On the agenda were the EEC Conventions and Drafts. ${ }^{77 a}$ An expert from the United States was at the Ford Workshop.

The literature on the draft had been growing steadily. In the United States, David Cavers had written on the draft. ${ }^{78}$ The present writer had a paper on it with the title "Impressionism and Unification of Law," in which the Restatement-like character of the draft was noted and the possibility of any true unification of the law by this approach questioned. ${ }^{79}$ Willis Reese paid special attention to "the future of contracts and torts" in his Hague Academy Lectures of July $1976 .{ }^{80}$ International concern about the Market project was clear.

The 13th Session of the Hague Conference took place in October 1976. The "Future Work" item was assigned to Committee IV, which was chaired by the Swiss delegate who also had presided over the Special Commission meeting of January 1976. In Committee IV the United States delegation proposed that Contracts be included in the future work list of the Conference. ${ }^{81}$ As

75. The materials are in European Private International Law of Obligations, supra note 59 .

76. The Law Commission and the Scottish Law Commission, Private International Law, eEC Preliminary Draft Convention on the law Applicable to Contractual and Non-Contractual Obligations, Consultative Document (August 1974).

77. Neither the answers received nor findings, if any, of the Law Commissions have been published. For a discussion from the English side, see Collins, Contractual Obligations-The EEC Preliminan Draft Convention on Private International Law, 25 INT'L \& Comp. L. Q. 35 (1976).

77a. See Great Britain, Law Commission (Law Com. No. 78), Eleventh Annual Report, 1975-1976, p. 7, \&\$33, 34 (1977).

78. Cavers, The Common Market's Draft Conflicts Convention on Obligations: Some Preventive Law Aspects, 48 S. CAL. L. REv. 603 (1975).

79. Nadelmann, Impressionism and Unification of Law: The EEC Draft Convention on the Law Applicable to Contractual and Non-Contractual Obligations, 24 АM. J. CoMP. L. 1 (1976).

80. Reese, Choice of Law in Tort and Contracts and Directions for the Future, 16 Colum. J. TRANSNAT'L L. 1 (1977).

81. See Minutes of afternoon, Oct. 12, 1976, Sess., Commission IV, Procès-Verbal No. 3, to appear in ConfÉrence de LA HAYE, supra note 68. 
phrased by the Chairman, the issue to be voted on was a suggestion to the Conference that the Conference recommend to the Netherlands Standing Committee inclusion of Contracts in future work. Delegates from most of the Governments represented at the Session participated in the ensuing discussion. The division was along "party lines." The result may be given without anything further. A first vote produced a tie. Ten delegations voted for and ten against, with four, namely, the Netherlands, Switzerland, the United Kingdom, and Spain abstaining. On the second vote Spain joined the opponents. The proposal thus was lost by a vote of ten to eleven, the Netherlands, Switzerland, and the United Kingdom abstaining. While represented at the Session, Argentina, Brazil, Israel and Turkey had no-one at the meeting. The United States was supported by Australia, Canada, Egypt, Finland, Japan, Norway, Sweden, Czechoslovakia, and Yugoslavia. The opposition was composed of Belgium, France, the German Federal Republic, Italy, and Luxemburg, Denmark and Ireland, Austria and Greece (declared EEC candidates), and Portugal and Spain (undeclared). In the discussion, one of the Swiss delegates had said that he personally favored an investigation on a broad basis; the same position had been taken originally by a Spanish delegate.

From the debate a statement made by an official of the EEC, present as observer, merits notation. According to him, the EEC would complete its codification work. Participation thereafter by the EEC in work on the same subject by the Hague Conference would be most unlikely.

The secretary general of the Hague Conference in his intervention took the line developed in the Permanent Bureau Note. A huge amount of preparation by the Bureau would be needed, creating manpower and financial problems. From the American side it was retorted that if, as proposed, a Special Commission were appointed, within its membership it would have all the expert knowledge needed to start the general discussion immediately. No mountain of documents from the Bureau was needed. Speaking as Chairman of the Netherlands Standing Committee, the President of the 13th Session remarked that, if the issue reached the Committee in connection with its jurisdiction over the Conference's program, in his view the Committee would consider that it had two responsibilities: first, to preserve the coherence and unity of the Conference and do everything necessary to avoid division of the Conference into different groups; and, second, to secure a useful program for the Conference within its financial means.

Obviously, the Hague Conference has reached a crisis in its life. Codification of the rules for Contracts has been left to a regional group. Before comments on the situation are offered, a related Conference event needs to be mentioned.

The 13th Session had three topics on its agenda, the law applicable to matrimonial property regimes, recognition of the validity of marriages, and 
the law applicable to agency. For the first two topics, drafts were produced at the session, ${ }^{82}$ but work on agency ran into trouble. Difficulties had been encountered already at the two pre-Conference sessions of the Special Commission on Agency. The Conference agreed to have a Special Commission continue the effort. The Special Commission met in June 1977 and produced a draft. $^{83}$

Agency had been put on the list of possible topics for future work with a low rating. The need for a convention had been questioned at earlier sessions. ${ }^{84}$ The Netherlands Committee picked it, presumably, for lack of a more appealing topic. The old Hague Conventions have been replaced. Most of the important topics have been attended to. ${ }^{85}$ The special problem with Agency now was that the part of Agency concerning the relations between principal and agent was straight contracts law. Work on Contracts was opposed but it was deemed all right to proceed with Agency.

Discussion of the merits of the Hague draft should await the availability of the report by the Rapporteur, but Article 16 on mandatory rules merits reproduction: ${ }^{86}$

In the application of the Convention, effect may be given to the mandatory rules of any State with which the situation has a significant connection, if and in so far as, under the law of that State, those rules must be applied whatever the law specified by its choice of law rules.

The Common Market Working Group having continued its work on Contracts, the provision is likely to represent current thinking by that group. A "may" has come to replace the "shall" in "shall be taken into account" of the original draft. ${ }^{87}$ After "legal impressionism" we now have unification of law through non-rules. Even for local codification it is no more than make-believe.

The lack of rules for contracts in countries such as Germany and Switzer-

82. See Reese, The Thirteenth Session of the Hague Conference, 25 Ам. J. Comp. L. 393 (1977); Amram, Report of the Thirteenth Session of the Hague Conference on Private International Law, 71 Ам. J. INT'L L. 500 (1977).

83. Text in Protocol of Closing Session, June 16, 1977, 16 Int'l Legal Materials 775 (1977).

84. See Conférence de La Haye, I Actes et Documents de la Neuvième (1960) Session 253, 283 (considered primarily in connection with sales).

85. See van Hoogstraten, L'état présent de la Conférence de La Haye de Droit International Privé, in The Present State of International Law and Other Essays Written in Honor of the Centenary Celebration of the International Law Association 1873-1973, 371,391 (M. Bos ed. 1973); Bolgar, Status of the Hague Conventions on Private International Law, 23 AM. J. Comp. L. 380 (1975). For current list of topics for future work, see Final Act of Thirteenth Session, "C", 25 Ам. J. Сомp. L. 394, 403 (1977).

86. Draft Convention on the Law Applicable to Agency, supra note 83.

87. Art. 7 of the 1972 draft, supra note 60 , at 588, read: "Where a contract is connected also with a State other than the State whose law is applicable under arts. 2, 4, 5, 6, 16, 17, 18, and $19(3)$, and where the law of that other State contains provisions regulating the subject matter in a mandatory way so as to exclude application of any other law, such provisions shall be taken into account to the extent that their particular nature or purpose can justify that exclusion." $C f$. Collins, supra note 77 , at 49 . 
land with codified conflicts rules is no accident but the result of strong opposition. ${ }^{88}$ Because, it is said, contracts is the field where certainty is lacking and most needed, search for rules is undertaken periodically. ${ }^{89}$ The result has always been the same. Restatement-type work raises a different question and it is possible that the Hague Conference could in this way make a valuable contribution.

\section{Reflections on the 13th Session of the Hague Conference}

In any assessment of the events of October 1976, care must be taken to avoid pitfalls. Contrary to appearance, even in the Code countries no agreement exists on codification of conflicts rules for contracts. The question is controversial everywhere. Furthermore, the apparent unity on the Market side is only for outside consumption. As many views exist as there are member States, each State having difficulty in formulating its own view. Finally, the voting down of the American proposal (rather than arriving at a compromise) was not inevitable but reflects poor handling by those entrusted with the interests of the Conference.

What did not need demonstration, but has been demonstrated, is the defect in the organizational set-up of the Conference. The Netherlands Standing Committee bears a responsibility too heavy for a national body, generally, and certainly under present world conditions. The Charter was written in 1951, the Common Market created in 1957. Even in 1951 the absolute control over the program given by the Charter to the Netherlands Committee was unwise. More subtle ways existed and exist to protect the financial concern of the Netherlands. If it existed, a Steering Committee on which all member governments are represented could have started work on the Market-Conference issue when it first surfaced. As on the earlier occasions a way out of the seeming impasse would have been found. If the Netherlands is agreeable to change, the Charter provides that amendments may be made with approval of two-thirds of the members. ${ }^{90}$

The Common Market has apparently chosen to pre-empt for itself codification of the rules of conflict of laws, thus blocking the Hague Conference from doing the job for which it was created. This is a heavy responsibility. Having the Conference operate at the Market's pleasure, to pick up crumbs here and there, is not likely to appeal to the other member States.

The specific substantive issue responsible for the current crisis, codification of conflicts rules for contracts in general, has wrecked meetings before and will continue to do so. As in the past, for lack of an acceptable solution,

88. For history and references see Nadelmann, supra note 79 , at 5 .

89. For a recent discussion see Vischer, The Antagonism between Legal Security and the Search for Justice in the Field of Contracts, 142 Recueil des Cours 1 (1974 II).

90. Charter, supra note 65, art. 12. 
recourse is had to what gives the appearance of a solution. In the EEC Draft of 1972, the "characteristic obligation" approach ${ }^{91}$ has been built up beyond what it can deliver. ${ }^{92}$ It is no more than one guideline among many; when overplayed in a statute or treaty, it risks sending courts on the wrong track.

The United States managed to reach its bicentennial without the benefit of codified conflicts rules, and this notwithstanding the existence of power under the Constitution to regulate the field..$^{93}$ Non-use of that power has been no accident. ${ }^{94}$ On the European Continent, codifying conflicts rules for contracts has been under consideration for at least a hundred years. Again the failure to codify is no accident. With this history in mind, the thought occurs that the confrontation at The Hague may have been over a false issue. No more than a "cooling-off" period may be needed to enable the Hague Conference to function again.

Starting the Conference was not easy. The Conference's purpose is as valid today as it was in 1893 when T.M.C. Asser succeeded in launching the Conferences and in 1951 when Offerhaus gave them a new lease on life. The Conference has built up an outstanding record. ${ }^{95}$ A task like that of the Conference never ends. ${ }^{96}$ Past achievements suggest salvage by a common effort.

Regional work was done in the past without creating friction. ${ }^{97}$ Accommodation between regional groups and bodies working on a world-wide basis is no impossibility. The demonstration has been made. ${ }^{98}$ Good intentions are the principal requirement. ${ }^{99}$

91. EEC Draft of 1972, supra note 60, art. 4. See Nadelmann, supra note 79, at 10; Collins, supra note 77 , at 44 .

92. See Jessurun d'Oliveira, "Characteristic Obligation" in the Draft EEC Obligation Convention, 25 Ам. J. Сомр. L. 303, 306-13, 326 (1977). Cf. Droz, L'interprétation, par la Cour de justice des Communautés, des règles de compétence judiciaire européennes en matière de contrat, [1977] D.S. Chronique 287.

93. Special reference may be made to the Full Faith and Credit Clause, U.S. Const. art. IV, $\$ 1$, which covers judgments and public acts. See Nadelmann, Full Faith and Credit to Judgments and Public Acts, 56 Mich. L. Rev. 33, 53, 71 (1957), reprinted in Conflict of Laws supra note 3, at 169, 205, 214.

94. See Cavers, Contemporary Conflicts Law in American Perspective, 131 Recueil des Cours 75, 109 (1970 III).

95. Between 1951 and 1977 twenty-six Conventions have been produced. Of the twenty-three written between 1951 and 1972/73 fourteen are in force. See van Hoogstraten, supra note 85.

96. Revision of two Conventions is under consideration; among new topics is work on child kidnapping. See list, note 85 supra.

97. Reference is made to the Conflicts Conventions adopted by the Scandinavian countries. See Philip, The Scandinavian Conventions on Private International Law, 96 RecueIL des Cours 245 (1959 I).

98. Of interest is the Report of the Legal Adviser of the Council of Europe, Methods of Coordination of the Activities of the Council of Europe, [1973] II UnIform L. Rev. 135. Representatives of non-member States have been invited to participate in some of the Council's unification-of-law work. See, e.g., Fleming, Draft Convention on Products Liability (Council of Europe), 23 Ам. J. Cомр. L. 729, 730 (1975). Some Council of Europe Conventions allow accession, upon invitation, by non-member States. See, e.g., European Convention of June 7, 1968, on Information on Foreign Law, Eur. T.S. No. 62, art. 18.

99. The Hague Conference and the Council of Europe have an agreement according to which 


\section{Developments on HemisPhere LeVel}

The problem faced by the United States on the inter-American level has similarities to what threatens the continued existence of the Hague Conference. The differences, however, are many. In the first place, the United States participated in the draft of the Charter for the Organization of American States as well as the draft of the amendments. Responsibility is shared for shortcomings in the organizational set-up. Second, on the factual side a grave problem is created by the isolation of the United States as the only Englishspeaking member and the only member from the common law world. ${ }^{100}$ The situation is further complicated by differences on the economic side.

In Latin America, as distinguished from Western Europe, knowledge of current conflicts law in the United States is the exception. Brazil has a leading jurist with a special interest in the American conflicts system. In the Spanishspeaking States, such coverage of American doctrine as exists rarely goes beyond "Vested Rights." 101 Recent development in Europe is not dealt with much better. The typical "old-style" treatise covers the domestic law and treaty law where the State is a party to the Montevideo Treaties, or the Bustamante Code, or both. Though change is on the way, ${ }^{102}$ the results are not felt yet. As for familiarity in the United States with conflicts law in Latin America, excepting the specialized Bar, the situation is hardly better, if a look is had at the teaching materials. The valuable volumes in the "Bilateral Studies" Series are not used. ${ }^{103}$ The growing interest at the law schools in

projects in the field of private international law are, in principle, turned over to the Hague Conference. Text of Agreement of Dec. 13, 1955 in [1959] Tractatenblad van het Koninkrijk der Nederlanden, No. 181, 9. Referred to in Nadelmann, Conflicts between Regional and International Work on Unification of Rules of Choice of Law, [1974] I UNIFORM L. REv, 44, 51, 15 HARV. INT'L L. J. 213, 224 (1974); Jessurun d'Oliveira, Universalisme ou régionalisme de la Conférence de La Haye, 55 ReVUe CRITIQUe de dRoIt INTERnational PRIVÉ 347, 381 (1966).

100. The admission to the OAS of new States from the Carribean "British-influence" area has not altered the situation fundamentally.

101. For a survey made some time ago see Nadelmann, Literature in Latin America on the Law of Conflict of Laws in the United States, 4 INTER-AM. L. REv. 103 (1962). Little has changed since.

102. In addition to growing local interest, the influence of literary production in Spain, leading in discussion of modern development, has begun to make itself felt in the Spanish-speaking world. Reference may be made, e.g., to M. Aguilar Navarro, Lecciones de Derecho Internacional Privado (2d ed. 1963-1964), J.A. Carrillo Salcedo, Derecho Internacional Privado (2d ed. Madrid 1976), the new Anuario de Derecho Internacional brought out by the University of Navarra, and the revitalized Revista Española de Derecho Internacional. For local interest see, e.g., Parra Aranguren, Las obligaciones extra-contractuales en derecho internacional privado, Revista de la Facultad de Derecho-Universidad Católica Andés Bello, 19741975, No. 20, 8; de Maekelt, El derecho international privado y Joaquin Sanchez-Covisa, in OBRA JURÍdica de Joaquin Sanchez-Covisa 13 (Carácas 1976).

103. Bilateral Studies covering: Colombia (Eder), Brazil (Garland), Chile (Etcheberry), Argentina (Goldschmidt \& Rodriguez-Novas), Venezuela (Lombard), and Mexico (Bayitch \& Siqueiros). See also the volume International Cooperation in Civil and Commercial Procedure: American Continent (L. Kos-Rabcewicz-Zubkowski ed. 1975). 
Latin American law has reached conflicts only at a few places. However great the value of materials for domestic purposes, the problem faced by unificationof-law work in the Organization of American States must be looked at against this background.

Technically, in the Organization of American States (OAS), under the Charter of Bogota of 1948 as amended in $1967,{ }^{104}$ the organ to advise on juridical matters today is the Inter-American Juridical Committee. ${ }^{105}$ Until the amendment of 1967, the top legal organ was the Inter-American Council of Jurists, now abolished. ${ }^{106}$ The Committee's assignment as presently phrased includes the promotion of the progressive development and the codification of international law and the study of juridical problems related to integration of the developing countries of the Hemisphere and, in so far as may appear desirable, the possibility of attaining uniformity in their legislation. The original document had spoken of promotion of the development and codification of public and private international law. ${ }^{107}$

The Inter-American Juridical Committee is composed of eleven members elected by the OAS's General Assembly. ${ }^{108}$ Election is from panels of three furnished by each of the more than twenty member States. Under the Charter the members represent all member States. The Committee meets in regular and extraordinary sessions in Rio de Janeiro, where it has its seat. It reports to the OAS on its work. The Reports become available in Spanish first and thereafter in other languages, including English. Individual reporting by members is rare. Since 1974, the members have taken a prominent part, however, in the teaching of a course on International Law given yearly in Rio de Janeiro under the Committee's auspices with assistance from the OAS and the Getulio Vargas Foundation. ${ }^{109}$ Often lectures deal with Committee work. The Rio Course is published by the OAS. ${ }^{110}$ Most lectures are in Spanish.

Because the Inter-American Juridical Committee has jurisdiction over both public and private international law, the governments face a problem with regard to the election of members. Generally, preference goes to candidates from the diplomatic, public international law sector. Thus the Committee is

104. Charter of Bogota of 1948, [1948] INTER-AM. JuR. Y.B. 296, as amended by Protocol of Buenos Aires of Febr. 27, 1967, T.I.A.S. No. 6847, 21 U.S.T. 659, 64 AM. J. INT'L L. 966 (1970).

105. Id., art. 105 .

106. See Zanotti, Regional and International Activities (hereinafter Zanotti), 2 LAw. AM. 229, 231 (1970)

107. Charter of Bogota, supra note 104, art. 67.

108. Charter, as amended, supra note 104, art. 107. See Zanotti, 2 LAw. Am. 431, 435 (1970).

109. See Zanotti, 7 LAW. AM. 124, 126-28 (1975).

110. Primer Curso de Derecho Internacional Organizado por el Comité Jurídico INTERAMERICANO (septiembre-octobre de 1974). Conferencias pronunciadas. OAS (CJI-26) 1975, mimeo. Segundo Curso (julio-agosto de 1975) OAS (CJI-28) 1976. Tercer Curso (julio-agosto de 1976) OAS (CJI-30) 1977. Cf. Zanotti, 9 LAW. AM. 161 (1977). 
no expert body on private international law. A member from that field may have it all for himself.

At the first Committee meeting, the member from Colombia, José Joaquin Caicedo Castilla, an authority on public and private international law, proposed work on revision of the Bustamante Code on Private International Law, ${ }^{111}$ a product of the Sixth International Conference of American States held in Havana in 1928. ${ }^{12}$ Fifteen Latin American States have ratified the Code Convention, six with a general reservation. ${ }^{113}$ Changes in the Code, the argument went, might make the Code acceptable to more States, in particular those in South America which are parties to the Montevideo Treaties of $1889^{114}$ and $1940 .{ }^{115}$ The Inter-American Council of Jurists reacted favorably to the proposal at its 1950 session. The assignment went to the Committee "to investigate the possibility of revision, in so far as advisable, of the Bustamante Code and the Montevideo Treaties and of the Restatement of the Law of Conflict of Laws, in order to make these three codifications uniform." ${ }_{116}$ As phrased, the assignment produced mixed reactions. ${ }^{17}$ Dr. Caicedo wanted the Restatement excluded from consideration. A further assignment asked for preparation of a comparative study of the three instruments. ${ }^{118}$ A technical study was produced by Dr. Caicedo. ${ }^{119}$ The Council of Jurists at its 1959 session rephrased the assignment, asking the Committee to consider possible revision of the Bustamante Code with the aim of obtaining uniformity of rules of conflict of laws in the different American States. ${ }^{120}$

The possibility of partial revisions was studied. One idea was to write into the Code a rule making the law of the domicile the governing law for per-

111. See Report of the Inter-American Juridical Committee, [1949] INTER-AM. JUR. Y.B. 320, 324.

112. 86 L.N.T.S. 111; The International Conferences of American States 1889-1928 (J.B. Scott ed. 1931) 367; 4 M. Hudson, International Legislation 2279 (1931). See Lorenzen, The Pan-American Code of Private International Law, 4 TUL. L. REv. 499 (1930).

113. References are given in Nadelmann, The Need for Revision of the Bustamante Code on Private International Law, 65 AM. J. INT'L L. 782 (1971).

114. English translation in 2 International American Congress, Reports of Committees And Discussions 876 (1890). See Nadelmann, Multilateral Conventions in the Conflicts Field: An Historical Sketch, 19 Nederlands Tijdschrift voor InternationaAl Recht 107, 121 (1972).

115. Translation in 37 AM. J. INT'L L. 95 (Supp. 1943). See Nadelmann, supra note 114, at 145; Argúas, The Montevideo Treaties of 1889 and 1940 and their Influence on the Unification of Private International Law in South America, in The Present State of International Law and Other Essays, supra note 85 , at 345 .

116. [1950-1951] INTER-Amer. JUR. Y.B. 289, 302.

117. Discussed in Nadelmann, $A$ New Report of the Inter-American Juridical Committee on Revision of the Bustamante Code, 53 AM. J. INT'L L. 652 (1959).

118. [1952-1954] INTER-AmER. JUR. Y.B. 192, 208 (Res. XII).

119. Inter-American Juridical Committee, Comparative Study of the Bustamante Code, the Montevideo Treaties, and the Restatement of the Law of Conflict of Laws (CIJ-21). Pan American Union, 1954, mimeo.

120. Inter-American Council of Jurists, Fourth Meeting, Santiago, Chile, 1959, Final Act 26 (Res. VII: Possibility of Revision of the Bustamante Code). 
sonal status questions. In the Code, this was left to the local law (which might be the law of the domicile or the national law). The parties to the Montevideo Treaties, it was thought, objected to the Bustamante Code primarily for that reason. ${ }^{121}$ Proposals for revision were prepared.

At its 1965 session the Council of Jurists decided to propose to the OAS that it call a specialized conference on revision of the Bustamante Code. ${ }^{122}$ Revision was to begin with the Code's "general principles" and the rules on civil and commercial law; rules on labor law were to be added. The Montevideo Treaties as well as the general evolution of the law was to be taken into account. The States were to be represented by specialists in private international law. The OAS staff was to publish in one volume all documents produced in connection with the revision project. The volume became available in $1967 .{ }^{123}$ One piece is a revised version of the Bustamante Code, prepared by Dr. Caicedo. ${ }^{124}$

In 1971, the General Assembly of the OAS decided to convene the specialized conference on private international law. ${ }^{125}$ The OAS Permanent Council was given the assignment to establish the agenda in consultation with the governments. Thereafter, the drafts for the Conference were to be prepared by the Inter-American Committee. The Committee on Legal and Political Affairs of the Permanent Council set up a Working Group for formulation of the agenda. Consultations of the governments revealed a definite preference by a majority for work on specific questions in the commercial law field. ${ }^{126}$ Better immediate results, it was thought, could be expected. Primary interest had shifted to creation of free trade areas in Latin America analogous to the European Market. Considerable attention was given to problems in the area of multinational corporations.

Eventually, a provisional agenda evolved with no less than eleven topics ${ }^{127}$ (to be indicated below). As instructed, the Inter-American Juridical Committee in 1973 prepared drafts (or recommendations) for all. ${ }^{128}$ All drafts, ex-

121. See Nadelmann, The Question of Revision of the Bustamante Code, 57 AM. J. INT'L L. 384 (1963).

122. Inter-American Council of Jurists, Fifth Meeting, San Salvador, 1965. Final Act 12 (Res. II: Possibility of Revision of Bustamante Code).

123. Textos de los Documentos de la Organización de los Estados Americanos sobre la Posibilidad de Revisión del Código de Derecho Internacional Privado o Código BustaMANTE (1967) (2d ed., rev., 1970) (CIJ-90 Rev.). Replaced by Documentos de la Organización de los Estados Americanos sobre Derecho Internacional Privado. June 1973 (CJI-15).

124. In Textos, supra note 123 , at 391 .

125. See Zanotti, 3 LAw. Aм. 563, 569-70 (1971).

126. The new trend had begun to manifest itself in the work of the Inter-American Juridical Committee. See references in Nadelmann, supra note 113 , at 785.

127. OAS Report on the Draft Agenda for CIDIP. CP/doc. $237 / 72$ rev. 20 Dec. 1972. See Zanotti, 5 LAw. AM. 98, 100-101 (1973).

128. Work Accomplished by the Inter-American Juridical Committee During its Regular Meeting (July 26 to August 27, 1973) (CJI-17). OAS Draft Conventions and other Documents on Topics 1 to 11 of the Draft Agenda for CIDIP prepared by the Inter-American Juridical Committee (CIDIP/3) March 1974. See Zanotti, 6 LAw. Aм. 463, 464-68 (1974). 
cept one, were by Dr. Caicedo. The specialized Conference was called to meet in Panama City from January 14 to $30,1975 .{ }^{129}$

The Conference was attended by all but three of the member States. From the provisional agenda six topics were chosen, three in the commercial law field and three in the area of judicial assistance. They were assigned to two separate committees. The Conference, in the Final Act, ${ }^{130}$ approved drafts for six Inter-American Conventions. ${ }^{131}$ The three commercial law conventions are on conflict of laws concerning bills of exchange, on conflict of laws concerning checks (provisional text), and on international commercial arbitration. The three other conventions are on service of documents and letters rogatory, on taking evidence abroad, and on the legal regime of powers of attorney to be used abroad. With respect to checks, the Conference recommended further consideration of the topic, both for conflicts and preparation of a uniform substantive law.

In a Resolution, the Conference noted that, because of lack of time, only a few of the topics could be covered and that continuation of the work was deemed essential, with in-depth studies by specialists. The General Assembly of the OAS was urged to call a second specialized conference. In advance of the conference, a meeting of specialists from all States should take place to prepare the drafts. The drafts would then go to the Inter-American Juridical Committee for its comments and suggestions. These documents should be available to the governments to prepare for the conference.

Wide ratification of at least some of the conventions seems to be expected in Latin America. ${ }^{132}$ No report of the United States delegation to the Panama Conference has appeared. Only the Arbitration Convention ${ }^{133}$ and the principal convention on judicial assistance ${ }^{134}$ have been discussed in our journals.

The General Assembly of the OAS complied with the wish expressed for a second specialized conference without losing time. A Resolution with the call

129. See Zanotti, 6 LAw. AM. 777, 781 (1974).

130. OAS, Conferencla Especializada Interamericana sobre Derecho Internacional Privado (CIDiP), Acta Final-Final Act-Ata Final-Acte Final (Washington, D.C. 1975). See Zanotti, 7 Law. Am. 385, 386-96 (1975).

131. Text of the Conventions in the four languages in OAS, Serie sobre Tratados, Nos. 40 to 45 (40: Bills of Exchange; 41 : Checks; 42: Arbitration; 43: Letters Rogatory; 44: Evidence Abroad; 45: Powers of Attorney). English text in 14 Int'l Legal Materials 325 (1975).

132. See Zanotti, 8 LAw. AM. 815, 821 (1976); Parra Aranguren, La Primera Conferencia especializada interamericana sobre derecho internacional privado, 16 ACTAS PROCESAles del DeRECHo vivo, Nos. 46-48, 307 (Venezuela, July 1975). Cf. Lectures at the Second, July-August 1975, Course given in Rio de Janeiro, supra note 110 , at 247-356; M. Vieira, D. Opertti \& E. Gonzales Lapeyre, Convenciones de Panamá 35-75 (Montevideo 1975).

133. Convention Text in Norberg, Inter-American Commercial Arbitration Revisited, 7 LAw. AM. 275, 286 (1975); Committee on Arbitration, Association of the Bar of the City of New York, The Inter-American Convention on International Commercial Arbitration, 9 LAw. Am. 43 (1977). Cf. Abbott, Latin America and International Arbitration Conventions: The Quandary of Non-Ratification, $17 \mathrm{H}_{\mathrm{ARV}}$ INT'L L.J. 131 (1976).

134. Carl, Service of Judicial Documents in Latin America, 53 Denver L.J. 455 (1976) (text of the Letters Rogatory Convention at 472). 
of Conference II was passed at the May 1975 session. ${ }^{135}$ The offer of Uruguay to act as host was accepted. The Permanent Council was given the task of preparing the agenda. The Inter-American Juridical Committee was asked thereafter to prepare the drafts. The recommendation that a meeting of experts be called to make the drafts was disregarded. The Secretariat was given the assignment of preparing technical studies for the topics.

The provisional agenda for the Conference has eight topics, essentially those which were on the agenda for Conference I but were not acted on. The topics are: ${ }^{136}$ (1) recognition of judgments, (2) compliance with provisional measures granted in judicial proceedings, (3) proof of and information on foreign law, (4) checks, (5) updating conflicts rules regarding business associations, (6) international sales, (7) maritime transport, and (8) general rules on private international law. The Inter-American Juridical Committee had prepared drafts for most of these topics in $1973 .{ }^{137}$

The Inter-American Juridical Committee spent its July 1976 and January 1977 sessions on the topics. Changes had occurred in the Committee's membership. Because of the work by UNCITRAL, nothing was done on Sales. Production of a uniform law on checks also was shelved. On all other topics, except checks (conflicts) and general rules of private international law, work was completed. ${ }^{138}$ The draft on recognition of judgments was rewritten. ${ }^{139}$ Some of the other drafts were revised. ${ }^{140}$ The work on business associations produced dissents from the Committee draft and two separate drafts. ${ }^{141}$ Work on checks and general principles of private international law was to be completed in July 1977. The Secretariat has produced technical studies-some with outside assistance-for certain topics, ${ }^{142}$ and more studies are on the way.

135. See Zanotti, 7 Law. Am. 686, 691 (1975).

136. See Zanotti, 8 LAw. Am. 448, 454 (1976).

137. The 1973 drafts are in Work Accomplished, supra note 128.

138. OAS, Proyectos de Convenciones y otros documentos sobre los temas 1 al 8 del Proyecto preliminar de temario de la Cidip Il, preparados por el Comité Jurídico INTERAMERICANO EN SU PERIODO ORDINARIO DE SESIONES CELEBRADO DEL 12 DE ENERO AL 18 DE FEBRERO DE 1977 (CIDIP-II/8: 16 matzo 1977).

139. Draft at 7, supporting statement by Haroldo Valladāo at 11. See Zanotti, 9 LAw. AM. 371 , 374 (1977). The jurisdictional test (art. 1(d)) for recognition is that (a) the original court must have had jurisdiction under its own law and (b) the legislation of the state of recognition does not claim exclusive jurisdiction for the subject matter.

140. With respect to the Draft on Provisional Measures, at 27, Dr. Valladão points out (at 43) that this should be treated in connection with recognition of judgments. The draft on information regarding foreign law, at 4 , allows the courts through diplomatic channels to ask the country of the applicable law for information on its law, the text and its interpretation (art. 4). See Zanotti, 9 LAW. AM. 371,376 (1977).

141. Committee draft at 59, 63; dissent by Aja Espi at 66, Ricaldoni at 68 . Individual draft for multinational enterprises by Ruiz Eldredge at 74; individual drafts by Caicedo Castilla and Valladão at 79 and 90 , respectively.

142. Recognition of Foreign Judgments: CIDIP-II/3, Sept. 1976 (with assistance from Opertti Badan (Montevideo)); Compliance with Provisional Measures: CIDIP-11-4, August 1976 (with assistance from Monroy Cabra (Colombia)); Proof and Information regarding Foreign Law: 
Discussion of the drafts would be out of place. Some of them were prepared, as the supporting statements make clear, with only Latin American law in mind. Dr. Caicedo, the Committee's current president, never hid his view that the unification work should be restricted to Latin America. With respect to other drafts, the situation is not as obvious, but no effort to make them acceptable also to the United States can be detected. Of the available technical studies prepared by the Secretariat, it should be said that information on the law in the United States is included.

A realistic appraisal of the situation is called for. Dr. Caicedo does not speak for Latin America and the pitfall must be avoided of considering Latin America as a unit with the same position on the subject. However, the view that unification work should be restricted to Latin America is held widely. When unification of "inter-American private international law" is discussed among Latin Americans, almost always the inter-Latin American, not the inter-American (our expression), system is meant. The reference is to the Montevideo Treaties and the Bustamante Code and their accomplishments. ${ }^{143}$ No inter-American system exists. The desirability and feasibility of its creation have not been demonstrated. Dr. Caicedo may be right in his view but the consequences ought to be drawn. Latin American work should not be under the auspices of the OAS, a truly inter-American organization. OAS work ought to be restricted to bona fide inter-American efforts, which should be so conducted that positive results can be expected. This means recourse to an expert body on private international law, not the Inter-American Juridical Committee. On this basis the choice of the topics would have to be re-examined. What is suitable for an inter-American, that is, Hemisphere, effort? I say. "Hemisphere effort" for, while Canada is still not in the OAS, its existence should not be overlooked for this type of project.

The United States has never favored general codification of private international law, regionally or internationally. Regional codification has the double disadvantage of creating different conflicts rules for different areas. Codification of rules for given topics raises an entirely different problem. Depending upon the topic, regional work may or may not be desirable. For none of the topics on the provisional agenda of Conference II is it clear that inter-American, as distinguished from international, work might be indicated.

CIDIP-II/9, March 1977 (with text of the European Convention on Information on Foreign Law, supra note 98 , in appendix).

143. See, e.g., Caicedo Castilla, Contribución de America al desarrollo del derecho internacional: Realizaciones del Comité Jurídico Inter-Americano, in TerCer Curso, supra note 110, at 13. The part on the Restatement (at 29) reads: "The Restatement applies solely in the United States which do not conclude treaties in the matter because, in accordance with its federal system, regulation of civil and commercial law questions is under the jurisdiction of the individual states of the Union." (my translation). C $f$. J.J. Caicedo Castilla, Derecho Internacional Privado 47 (6th ed. 1967). By way of comment it is sufficient to refer to the Commerce Power, U.S. Const. art. I, $\$ 8$, and to Missouri v. Holland, 252 U.S. 416 (1920), for treaties. Cf. Nadelmann, supra note 114, at 144. 
The same problem arose for Conference $\mathrm{I}$. This is not to suggest that regional work for Latin America was not proper or desirable.

As regards international work, today Brazil and Argentina are members of the Hague Conference, Venezuela had observers at the last session and joining has been under consideration in Mexico. This fact must not be overlooked. For judicial assistance the Hague Conference has two excellent Conventions, ratified by numerous countries. ${ }^{144}$ Latin America did not participate in the drafting, but does this suggest incompatibility with all Latin American legal systems? Upon examination the contrary is likely to be found for at least some Latin American States. Use of these Conventions has the advantage of creating a link between them and all parties to the Conventions. The United States is about to accede to a third Hague Convention, one in whose preparation it did not share, the Convention abolishing the Requirement of Legalization for Foreign Public Documents. ${ }^{145}$ Upon examination, Latin American States may find it equally useful. Duplication of international instruments without real need is poor policy.

A decision by Latin America to proceed with Latin American work would not leave the United States "uninterested." Production of conflicts rules anywhere with world-wide effect creates interest. The EEC closed-door policy could be replaced by an open door policy capable of securing mutual benefits. Recourse to an "observer" arrangement would be nothing new.

In the present status of affairs, the great Hemisphere problem is lack of sufficient contact between the specialists in the different American States. The difficulty exists even on the straight Latin American level. The Panama Conference has been praised for allowing personal contacts to be established. Easier ways can be imagined. ${ }^{145 a}$

In Europe, the courses taught at the Hague Academy of International Law in French or English have done miracles in broadening knowledge about foreign conflicts law. The Recueil des Cours has become an indispensible professional tool. ${ }^{146}$ At the Academy insufficient attention has been given to Latin American law, ${ }^{147}$ but this does not justify the neglect of this source of informa-

144. The post-War Hague Conventions have been published in Spanish in J. DE LA TORRE, Las Convenciones de la Conferencia de la Haya de Derecho Internacional Privado (Madrid 1974).

145. Convention of Oct. 5, 1961, supra note 7. See Message, S. Exec. Doc. L, 94th Cong., 2d Sess. (1976).

145a. At the Panama Conference of 1975 an Inter-American Association of Professors of Private International Law was formed, with the seat in Paraguay. Dr. Haroldo Valladão was elected president. See Parra Aranguren, supra note 132, at 336 n.78.

146. Listing until 1970 in von Overbeck, L'enseignement du droit international privé à l'Académie de droit international de La Haye de 1923 à 1970, in Hague ACademy of International Law-Jubilee Book 1923-1973 117 (R. Dupuy ed. 1973).

147. But see Vieira, Le droit international privé dans le développement de l'intégration Latinoaméricaine, 130 Recuerl des Cours 351, 393, 413 (1970 II); Valladão, Le droit international privé des 
tion in many Latin American writings.

With the Hague lectures in mind, at the end of the Second World War the Inter-American Academy of Comparative and International Law was set up in Havana. ${ }^{148}$ Operations stopped in 1959. An effort to restart the Academy in Peru failed. ${ }^{149}$ Today, there is the Rio de Janeiro Course of International Law but, notwithstanding gestures, ${ }^{150}$ for conflict of laws it has been a strictly Latin American affair. A course on conflicts law in the United States has still to be offered. ${ }^{151}$ For those in the United States interested in Latin American conflicts law, the trip to Rio is long. No course in English is offered. Re-establishment of the Academy is needed. But the availability of the printed Rio lectures must not be overlooked.

Problems of some magnitude incapable of easy solution exist. Fortunately, the difficulties are more tractable between neighbor States. Efforts on the Mexico-United States level to secure better familiarity on both sides with the respective conflicts rules have had their ups and downs but there are signs of current active concern. ${ }^{152}$

\section{Conclusions}

The new types of difficulties encountered in work on unification of rules for conflict of laws raise complex issues in a field not easy even without this kind of complication. The national interest is challenged. The issues have to be faced. Codification for the world of conflicts law without United States participation is unsound as a general proposition. The United States has to play its role, for itself and the other countries counting on it.

The opening part of this paper has referred to the lack of a proper base for the unification-of-law work within the government. As the developments

Etats américains, 81 Recueil des Cours 5 (1951 II). Cf. Valladáo, The Influence of Joseph Story on Latin American Rules of Conflict of Laws, 3 Aм. J. Comp. L. 27 (1954).

148. On the organization see Finch, Mexico Meeting of the International Bar Association, 38 AM. J. INT'L L. 685 (1944); Finch, Inter-American Academy of Comparative and International Law, 38 Aм. J. INT'L L. 688 (1944). Reports in 50 AM. J. INT'L L. 430 (1956), 51 AM. J. INT'L L. 97 (1957), 52 Am. J. Int'l L. 118 (1958). See Academia interamericiana de Derecho Comparado e Internacional, Cursos Monograficos (8 volumes, Havana, 1948-1960).

149. See E. Finch, Inter-American Academy of International and Comparative Law, 60 AM. J. INT'L L. 83 (1966).

150. Lectures from the United States side have been on problems of multinational corporations. Production by the sponsors of Spanish versions of suitable Hague Academy lectures may be worth consideration. Cavers, Contemporary Conflicts Law in American Perspective, 131 Recueıl des Cours 75 (1970 III), comes to mind immediately.

151. A particularly instructive lecture is Valladāo, La importancia de la actualización de las normas de derecho internacional privado en las relaciones interamericanas, in PrIMER CURso, supra note 110 , at 185 .

152. In October 1977, a "First National Seminar on Private Internaţional Law" was held at the Autonomous National University of Mexico with participation from the United States side. "Institutes" held with some regularity in this country have concentrated on foreign investment problems. 
surveyed in this article will, I trust, have demonstrated, the situation is one that calls for a commitment by the government of resources in excess of those that have thus far been made available to it. Though one may hope for a more immediate, self-generated response, it seems doubtful that governmental activity will rise to an adequate level unless the need for its enlargement is clearly appreciated within the legal profession. Accordingly, my closing remarks will be on professional preparedness or the lack of it.

The bibliographies show the extent to which work on the international level is covered in our journals. If everything which has appeared at different places is put together, the picture is not entirely unfavorable. The results of the Hague Conference sessions have been reported regularly. ${ }^{153}$ Occasional articles have appeared on UNCITRAL work. ${ }^{154}$ But no regular briefing on developments abroad takes place. To keep up to date, the specialist has to make the rounds of the specialized foreign journals. The profession at large is left in the dark. This unfortunate state of affairs is due to the lack of an American journal with responsibility for the international conflicts field. The lack of a journal again results from the absence of an organization comprising the specialists. Presently, the interests in the field are neither watched over nor fostered properly. Luncheons of practitioners and occasional round tables at teachers' meetings are valuable but they do not do the job.

In another article I reported recently the state of affairs abroad, listing the specialized journals and the back-up organizations. ${ }^{155}$ The situation is well known to the American specialist. I will not burden this paper by repeating it. In my paper, I concluded that an American journal on private international law is needed. ${ }^{156}$ The problems discussed in the present paper show the urgency. A properly run journal keeps the profession up to date. It makes sure that attention is paid to problems which must be faced. Our own rewarding experience in the public international law field demonstrates this.

A strong back-up organization is needed. An American society devoted to the problems in international conflict of laws will fill a gap which has long been felt in the field. Production of a first-rate journal is a major project. Financing must be proper. During the early stage at least, the journal cannot, and should not, be run on a shoe-string basis. With the proper approach, what has been possible abroad can be accomplished in the United States.

153. In the American Journal of Comparative Law.

154. In addition to working on the Uniform International Sales Law and related problems, UNCITRAL has produced a draft of a Convention on the Carriage of Goods by Sea (text in $8 \mathrm{~J}$. Mar. L. \& Coм. 267 (1977)), to be submitted to a United Nations Conference, has written Arbitration Rules (text in 2-1977-Yearbook Commercial Arbitration 161 (Int'l Council for Com. Arbitration ed. 1977)), and is engaged in production of a new International Negotiable Instrument (progress reports in the UNCITRAL Yearbook).

155. Nadelmann, Internationales Privatrecht: A Source Book on Conflicts Theory Analyzed and Reviewed, 17 HaRv. INT'L L.J. 657, 676 (1976).

156. Id. at 675 . 
Contrary to a view popular in some quarters, conflict of laws is not an academic subject, one where only the doctriniste has a field day. The problems of international business are attended to, as are problems of personal and family relations. Intellectual speculation invited by the difficulties in the field does not remove the practical side. In the journals abroad, the core is on litigation (cases), legislative changes, work by international agencies, and publications in the field. Certainly, the realities are acknowledged by the business world. They have to, if only because of the amounts spent on consultations and litigation involving problems in the conflicts field. Compared with these expenses, what is needed for a good journal is de minimis. In a realistic assessment of the situation in Germany after the First World War, German industry insisted on creation of proper services (now executed by well-known institutions). ${ }^{157}$ Financial support has come from the business side also elsewhere. American business is no less concerned about its interests. ${ }^{158}$

Special difficulties are faced in the United States. The journal has to confront the fact that the profession's first interest is in interstate conflicts cases covered adequately by domestic publications. Duplication must, and can, be avoided. The foreign readers' interest is in an overview of the field as a whole. As for the domestic reader, because American activities are spread all over the globe, he may expect coverage of vast territory. A selective approach is needed. The responsibility will be with the editorial board which must reflect the principal areas of interest, territorial and other.

On the positive side, primarily due to its federal structure, the United States has remained the great laboratory for the field of conflicts. Developments in the United States-court decisions, Restatement work, doctrinal argument-are followed closely abroad. The American challenges of late were not received with open arms everywhere, answers have not always been responsive, ${ }^{159}$ but the so-called American revolution has secured the respect it is entitled to. Today the shortcomings of the "traditional" approach" ${ }^{\mathbf{1 6 0}}$ are recognized. Reassessment of approaches and values takes place everywhere. ${ }^{161}$

157. Covering private international and comparative law, RABELs ZeITSCHRIFT is published by the Max-Planck-Institut für ausländisches and internationales Privatrecht in Hamburg.

158. Generous support is given to international law journals, "senior" and "junior."

159. Sometimes criticism has concentrated on the proposal easiest to find fault with. The broad argument has been made that "the proposals" can work only in a federal system, and often the suggestion is advanced that approaches are not suited for Code systems, where, in fact, in most Code countries conflict of laws is not codified, or codified in such a way as to furnish little or no guidance to the courts. Some reactions abroad are noted in Juenger, Trends in European Conflicts Law, 60 Cornell L. Rev. 969, 970-72 (1975).

160. See Cavers, A Critique of the Choice-of-Law Problem, 47 Harv. L. Rev. 173 (1933).

161. For a recent discussion, with ample bibliographical references, in the Hague Academy Series see Ferrer-Correia, Les problèmes de codification en droit international privé, 145 RecueIL DES Cours 57, 82-96 (rapprochement entre les perspectives américaine et européenne) (1975 II). Cf. P. Mayer, Droit International Prive 87-113 (pluralité des méthodes) (Paris 1977); G. Kegel, Internationales Privatrecht 92-96 (4th ed. 1977) (complete bibliography). 
Whatever history's findings on the value of approaches suggested by different authors in the United States, ${ }^{162}$ intellectual effort everywhere has reached levels rarely attained. Once again lasting contribution has come from this side of the Atlantic.

Fulfilling a need, the American journal of private international law which is proposed may serve also as a memorial for a significant period in the history of an alluring, never dull field. A journal as conceived can fight provincialism at home and bias abroad. It will make sure that the field is given a place in the concerns of government and the legal profession commensurate with its national importance.

162. "As in all branches, especially in that of choice of law, a pioneer spirit has come to permeate theoretical writing and judicial practice. Traditions are being broken, experiments are undertaken, and ideas, novel or believed to be novel, are propounded, opposed and tested. The practical results appear mostly sound even though some of the new theories are questionable." Rheinstein, United States of America, in I InTERNational Encyclopedia of Comparative Law: National Reports, U-131, 158 at 162 (1976). 